\title{
Effects of boron compounds on human reproduction
}

\author{
Hermann M. Bolt ${ }^{1}$. Nurşen Başaran ${ }^{2}$ Yalçin Duydu ${ }^{3}$ \\ Received: 13 February 2020 / Accepted: 5 March 2020 / Published online: 13 March 2020 \\ (c) The Author(s) 2020
}

\begin{abstract}
Because of the high $\mathrm{pK}_{\mathrm{a}}$ of boric acid, inorganic borates, when taken up by the human or animal organism, exist in the body almost exclusively in the form of non-dissociated boric acid. Therefore, the variety of inorganic boron compounds is commonly addressed in the toxicological literature as "boron" (B). There is a discussion concerning categorisation of inorganic boron compounds as reproductive toxins. Boron treatment of rats, mice and dogs was dose-dependently associated with testicular toxicity, characterised by inhibited spermiation at lower dose levels and by reduction of epididymal sperm counts at higher dose levels. The NOAEL for such fertility effects of boric acid in male rats (oral feeding, Sprague Dawley strain) was evaluated to be $17.5 \mathrm{mg} \mathrm{B} / \mathrm{kg}$ bw per day. As far as developmental toxicity is concerned, oral dosing of $9.6 \mathrm{mg} \mathrm{B} / \mathrm{kg}$ bw daily to female pregnant Sprague Dawley rats remained without effects, with foetal skeletal effects observed at higher doses. Therefore, $9.6 \mathrm{mg} \mathrm{B} / \mathrm{kg}$ bw (oral dosing) was evaluated as NOAEL for developmental effects of boric acid. The blood level in rats, equivalent to this NOAEL, is $1270 \mathrm{ng} \mathrm{B/g}$. As far as B-exposed humans are concerned, field studies on the effect of boron on human reproduction are possible only in a few boron-rich geographical areas. Published field studies were conducted in China's Liaoning province, the Argentinian Andes and Western Anatolia/Turkey. Particularly relevant are studies on occupationally B-exposed groups, because the potential exposure to boron is much higher in occupational compared to environmental settings. Comparison of estimated daily B exposure levels in humans and actually measured B blood levels confirms the preference of biomonitoring for exposure assessment in environmental and occupational studies. A boron blood level scaling shows that the levels of high occupational B exposures reported in China and in Turkey are compatible. Compared to the experimental B blood levels at boron-related NOAELs for male fertility and for developmental toxicity in rats, the human blood level means of the highest occupational exposure groups in China and in Turkey are lower by factors of $>4$ and $>2$, respectively. Basically, concentrations of B within the body that exert reproductive toxicity in humans are not reached under the conditions of human normal handling and use, including conditions of extreme occupational exposures. In consequence, all relevant results of studies into human reproductive toxicity of B are basically negative. Considering the effective doses, there is no scientific contradiction between experimental and human results of B reproductive toxicity.
\end{abstract}

Keywords Boron $\cdot$ Boric acid $\cdot$ Borates $\cdot$ Reproductive toxicity $\cdot$ Fertility $\cdot$ Development

\section{Introduction}

Hermann M. Bolt bolt@ifado.de

1 Department of Toxicology, Leibniz Research Centre for Working Environment and Human Factors at TU Dortmund (IfADo), Ardeystr. 67, 44139 Dortmund, Germany

2 Department of Pharmaceutical Toxicology, Faculty of Pharmacy, Hacettepe University, Ankara, Turkey

3 Department of Pharmaceutical Toxicology, Faculty of Pharmacy, Ankara University, Ankara, Turkey
There is a global interest in regulatory aspects of boron compounds, particularly in North America (Moore 1997; ATSDR 2010) Japan (Hasegawa et al. 2013) and Europe (ECHA 2010; SCCS 2010). A major focus of discussion is on reproductive toxicology (Duydu et al. 2016). For fertility and developmental toxicity, boric acid has been classified by the European Union as a "Category 1B" compound of the Globally Harmonized System (GHS), associated with risk phrases R60-61 ("may impair fertility; may cause harm to the unborn child"). Furthermore, boric acid has been 
proposed as a "substance of very high concern (SVHC)", based on experimental studies.

By contrast, experimental studies also displayed beneficial effects of boron on reproductive functions. For instance, dietary boron supplementation (40 ppm) in male goats increased sperm output, sperm mobility and enhanced immune and antioxidant defence capacity (Krishnan et al. 2019), and a boron-deficient diet produced a negative impact on early embryonic development in rats (Lanoue et al. 1998). Inorganic boron compounds may counteract genotoxicity (Marat et al. 2018). Furthermore, evidence is accumulating that boron is nutritionally important (Nielsen 2000, 2008), an aspect of potential impact in animal health and production (Basoğlu et al. 2017; Abdelnour et al. 2018).

This complex situation has led to a dispute as to whether a categorisation of inorganic boron compounds as reproductive toxins is justified. The present review will highlight studies that contribute to this discussion.

\section{Toxicokinetics of boric acid}

Because of the high $\mathrm{pK}_{\mathrm{a}}$ of boric acid, inorganic borates taken up by the human and animal organism exist almost exclusively in the form of non-dissociated boric acid. Therefore, the variety of inorganic boron compounds is toxicologically addressed as "boron". The internationally preferred common dose measure is $\mathrm{mg} \mathrm{B}$, related to body weight.

The toxicokinetics of boric acid have been studied in animals and in humans (Jansen et al. 1984; Ku et al. 1991; Usuda et al. 1998; Murray 1998). Orally administered boric acid and borates are readily and completely absorbed and distributed and are renally excreted as boric acid. Because of the absence of metabolism elimination kinetics appear very similar for rodents and humans; minor species differences are owing to differences in glomerular filtration rates (Murray 1998).

As a result, there is a linear coherence between the boron dose/intake upon repetitive administration and boron levels in organs, including the testes. This was experimentally demonstrated in rats for a dose range up to $9000 \mathrm{ppm}$ boric acid in the diet, equivalent to a dose of $68 \mathrm{mg} \mathrm{B} / \mathrm{kg}$ bw per day (Ku et al. 1993).

\section{Reproductive toxicity studies in animals}

\section{Fertility}

Studies on the reproductive toxicity of boric acid pointed to testicular atrophy after high-dose boron treatment of male rodents. A Reproductive Assessment by Continuous Breeding (RACB) study using mice exposed to boric acid at 1000 ,
4500, and $9000 \mathrm{ppm}$ in the diet indicated multiple sites of toxicity, with male fertility appearing as a sensitive endpoint. Decrements in sperm motility were observed at all exposure levels and testicular atrophy was confirmed in high- and middle-dose group males (Chapin and Ku 1994).

This was investigated further by timed serial sacrifice studies using $9000 \mathrm{ppm}$ boric acid in the diet of rats, which found that the first lesion in the testis was an inhibition of spermiation (release of mature spermatids). With continued dosing, this was followed by a disorganisation of the normal ordered layering of the seminiferous epithelium, germ cell sloughing and death, and finally atrophy. Subsequent studies using additional boric acid doses $(2000,3000,4500,6000$, and $9000 \mathrm{ppm}$ ) found that it was possible to observe inhibited spermiation that did not progress to atrophy $(4500 \mathrm{ppm}$ and below) within the 9-week exposure period. Also, once atrophic (from 9000 to $6000 \mathrm{ppm}$ exposures), there was no return of spermatogenesis after refeeding of normal diet for $8,16,24$, or 32 weeks, despite the presence of a normalsized population of spermatogonia that was seen to divide. No effects were observed in rats treated with $2000 \mathrm{ppm}$. Testicular boron concentrations remained steady during exposure at the same level as found in blood and declined to background levels within $72 \mathrm{~h}$ after cessation of exposure. Bone boron levels were higher than in blood and maintained slightly elevated levels even 32 weeks after the cessation of exposure. These studies document the effects of boric acid on functional and structural aspects of the male reproductive system, demonstrating that the tissue concentration of boron, and not total dose, is important for the testicular toxicity and they indicate a threshold for these effects (Weir and Fisher 1972; Chapin and Ku 1994; Price et al. 1996).

In essence, boron treatment of rats, mice and dogs was dose-dependently associated with testicular toxicity, characterised by inhibited spermiation at lower dose levels, and by reduction of epididymal sperm counts at higher dose levels (Weir and Fisher 1972; Fail et al. 1991; Ku et al. 1993). The NOAEL for fertility effects of boric acid in male rats (oral feeding, Sprague Dawley strain) was evaluated to be $17.5 \mathrm{mg}$ $\mathrm{B} / \mathrm{kg}$ bw per day [evaluation of ECHA (2010), based on the data of Weir and Fisher (1972)].

\section{Developmental toxicity}

The developmental toxicity of boric acid (given orally) was investigated in rats, rabbits and mice, within the framework of the US National Toxicology Program (Heindel et al. 1992, 1994). Boric acid was provided in the feed to mice and rats at $0,0.1,0.2$, or $0.4 \%$ throughout gestation. Average doses (mg/kg/day) were 248,452 , or 1003 for mice, and 78,163 , or 330 in rats. A separate group of rats received $0.8 \%$ boric acid in the feed or $539 \mathrm{mg} / \mathrm{kg} /$ day only on gestation days $6-15$. Rabbits were given boric acid $(0,62.5,125$, 
or $250 \mathrm{mg} / \mathrm{kg}$ ) by gavage on gestation days $6-19$. Maternal body weight, food and/or water consumption and signs of toxicity were monitored at regular intervals. At termination, on gestation days 17 (mice), 20 (rats), or 30 (rabbits), the uterus was examined to determine the number of resorptions, dead or live foetuses. Mouse dams exhibited mild renal lesions (at $248 \mathrm{mg} / \mathrm{kg} /$ day boric acid and above), increased water intake and relative kidney weight (1003 mg/ $\mathrm{kg}$ /day boric acid), and decreased weight gain during treatment. Maternal rats exhibited increased liver and kidney weights at $2163 \mathrm{mg} / \mathrm{kg} /$ day boric acid, altered water and/ or food intake at $>163 \mathrm{mg} / \mathrm{kg} /$ day boric acid, and decreased weight gain at $>330 \mathrm{mg} / \mathrm{kg} /$ day boric acid. In rabbits, signs of toxicity included decreased food consumption during treatment and vaginal bleeding associated with pregnancy loss at $250 \mathrm{mg} / \mathrm{kg} /$ day. Maternal body weight (gestational days 9-30), weight gain during treatment, and gravid uterine weight decreased at $250 \mathrm{mg} / \mathrm{kg} /$ day. Relative maternal kidney weight (but not absolute weight) was increased at $250 \mathrm{mg} / \mathrm{kg} /$ day, but microscopic evaluation did not indicate any renal pathology associated with exposure. It was concluded that boric acid is a developmental toxicant in all three species. The lowest-observed-adverse-effect level (LOAEL) for developmental toxicity was $78 \mathrm{mg} / \mathrm{kg} /$ day for rats (foetal weight reduction), $250 \mathrm{mg} / \mathrm{kg} /$ day for rabbits (prenatal mortality and malformations), and $452 \mathrm{mg} / \mathrm{kg} /$ day for mice (foetal weight reduction). The no-observed-adverse-effect levels (NOAELs) for developmental toxicity in these species were $<78 \mathrm{mg} / \mathrm{kg} /$ day (rats), $125 \mathrm{mg} / \mathrm{kg} /$ day (rabbits), and $248 \mathrm{mg} / \mathrm{kg} /$ day (mice). With regard to maternal toxicity, the rat was the most sensitive $(163 \mathrm{mg} / \mathrm{kg} /$ day $)$, while both the mouse and rabbit showed maternal toxicity at $250 \mathrm{mg} / \mathrm{kg} /$ day. Thus, developmental toxicity occurred below maternally toxic levels in the rat and in the presence of maternal toxicity in mice or rabbits.

Related to elementary boron, decreased foetal weights were noted in the above-mentioned study of the US National Toxicology Program at $13.7 \mathrm{mg} \mathrm{B} / \mathrm{kg}$ bw per day in absence of maternal toxicity (Heindel et al. 1992). In a subsequent study (Price et al. 1996), oral dosing of $9.6 \mathrm{mg} \mathrm{B} / \mathrm{kg}$ bw daily to pregnant Sprague Dawley rats remained without effects, with foetal skeletal effects observed at higher doses. Thus, $9.6 \mathrm{mg} \mathrm{B} / \mathrm{kg}$ bw (oral dosing) was evaluated as NOAEL for developmental effects of boric acid (WHO 1998; ECHA 2010; WHO 2011).

\section{Combination of toxicokinetic and reproductive toxicity data}

Subsequent to their studies of developmental toxicity, Price et al. (1997) studied the blood levels reached under the experimental conditions of the preceding study. For this reason, timed-mated Sprague Dawley rats (28-32/group) were exposed to boric acid in the diet from gestational days 0-20. Dietary concentrations of added boric acid were identical to those of the preceding developmental toxicity study and yielded average daily intakes of $0,3,6,10,13$, or $25 \mathrm{mg}$ boron/kg body weight (rounded values). Increasing dietary concentrations of boric acid were correlated with the whole blood boron concentrations in confirmed pregnant rats, amounting to $0.229 \pm 0.143,0.564 \pm 0.211,0.975 \pm 0.261$, $1.27 \pm 0.298,1.53 \pm 0.546$, and $2.82 \pm 0.987 \mu \mathrm{g} \mathrm{B} / \mathrm{g}$ blood (mean $\pm \mathrm{SD}$ ), from the control through high-dose groups. Maternal blood boron concentrations correlated with indices of maternal dietary intake of boron and with embryo/foetal toxicity that was observed at the two upper dose levels. The authors concluded that blood boron concentrations of $1.27 \pm 0.298$ and $1.53 \pm 0.546 \mu \mathrm{g} \mathrm{B} / \mathrm{g}$ blood were associated with the NOAEL (rounded to $10 \mathrm{mg} \mathrm{B} / \mathrm{kg} / \mathrm{d}$ ) and LOAEL (rounded to $13 \mathrm{mg} \mathrm{B} / \mathrm{kg} / \mathrm{d}$ ) for developmental toxicity, respectively (Price et al. 1997). Thus, the accepted NOAEL for rat developmental toxicity is equivalent to a blood level in rats of $1270 \mathrm{ng} \mathrm{B} / \mathrm{g}$.

The plausibility of these data can be checked against the independent data set of $\mathrm{Ku}$ et al. (1991), who performed a tissue distribution study in male Fischer rats at a daily oral dose of $9000 \mathrm{ppm}$ boric acid in the diet, i.e. 4.5-fold higher than the highest dose level of Price et al. (1996, 1997). From the 2nd day of treatment on, the plasma levels ranged between 14.03 and $16.37 \mu \mathrm{g} \mathrm{B} / \mathrm{ml}$. Assuming an equal distribution of $\mathrm{B}$ between blood plasma and blood cells (which is supported by an almost equal distribution in most tissues), this is about 5.3-fold higher compared to the highest dose level of Price et al. (1997). Considering the different rat strains used and remaining uncertainties in the whole blood/plasma distribution, both data sets appear compatible. This also implies no major sex differences. Hence, upon extrapolation of the data of Price et al. (1997), the commonly accepted NOAEL for rat male reproductive toxicity is equivalent to a blood level of about $2300 \mathrm{ng} \mathrm{B} / \mathrm{g}$.

\section{Reproductive toxicity studies in humans}

Field studies on the effect of boron on human reproduction are possible only in boron-rich geographical areas. Such areas are (semi)arid, with a history of geothermal activity. Published studies were conducted in China's Liaoning province, the Argentinian Andes and Western Anatolia/ Turkey. Particularly relevant are studies on occupationally $\mathrm{B}$-exposed groups, because the potential exposure to boron is much higher in occupational compared to environmental cohorts. 


\section{Studies in China}

Owing to the geological situation, high boron exposures are reported in parts of Northeast China, and are related to environmental, lifestyle and occupational factors (Chang et al. 2006).

Scially et al. (2010) compiled studies on nearly 1000 men and women in boron mining or processing in the Liaoning province of China. These included individual assessments of boron exposure, interviews on reproductive experience and data on semen analysis. Employed men living in the same community and in a remote community were used as controls. Boron workers $(n=75)$ had a mean daily boron intake of $31.3 \mathrm{mg} \mathrm{B} /$ day, and a subset of 16 of these men, employed at a plant where there was heavy boron contamination of the water supply, had an estimated mean daily boron intake of $125 \mathrm{mg} \mathrm{B/day.} \mathrm{Estimates} \mathrm{of}$ mean daily boron intake in local community and remote background controls were $4.25 \mathrm{mg} \mathrm{B/day} \mathrm{and} 1.40 \mathrm{mg} \mathrm{B/}$ day, respectively. Reproductive outcomes in the wives of 945 boron workers were not significantly different from outcomes in the wives of 249 background control men after adjustment for potential confounders. There were no statistically significant differences in semen characteristics between exposure groups, including in the highly exposed subset, except that sperm $\mathrm{Y}$ :X ratio was reduced in boron workers. Within exposure groups, the $\mathrm{Y}: \mathrm{X}$ ratio did not correlate with the boron concentration in blood, semen and urine. No compelling evidence of male reproductive effects attributable to boron could be obtained in highly exposed workers. This was supplemented by a further study of possible interactions of occupational boron exposures and semen quality that again found no significant correlations between blood or urine boron concentrations and adverse semen parameters (Robbins et al. 2010).

\section{Studies in Argentina}

The possibility of a reduction of birth weights related to boron was raised by a study of a population in the Argentinean Andes. This population was exposed to elevated concentrations of boron in the drinking water (Igra et al. 2016). The predominant industry in the study area was boron and lithium mining. It was reported that serum boron concentrations above $80 \mu \mathrm{g} / \mathrm{L}$ were inversely associated with length and weight of newborns. [All other studies give B concentrations per gram of whole blood.] However, it remains open whether boron was the causative agent in this case, because in the same population and at the same time also lithium exposure through drinking water was associated with impaired foetal size (Harari et al. 2015). Also, high altitude, which has a profound impact on birth weight (Jensen et al. 1997) may have confounded the data. Hence, no firm conclusions can be drawn from these studies.

\section{Studies in Turkey}

A first series of studies into human reproductive toxicity has been performed in environmentally exposed populations residing in boron-rich areas of Turkey with high drinking water levels and no clear-cut effects on reproduction were observed (Şaylı et al. 1998; Korkmaz et al. 2007). Also, fertility figures (Şaylı 1998; Şaylı et al. 1998; Korkmaz et al. 2011) and spontaneous abortions and stillbirths (Tüccar et al. 1998) showed no difference between subpopulations with high vs. low boron exposure.

To get an insight into the possible level of environmental exposure, Korkmaz et al. (2011) estimated daily B exposure in 66 males in Turkey living in a B-rich area. The average daily B exposure value was calculated as $6.77 \mathrm{mg} \mathrm{B}$ in the study group as opposed to $1.26 \mathrm{mg} \mathrm{B}$ in control areas.

In an occupational setting within a boric acid/borate production zone at Bandirma/Turkey Duydu et al. (2011) studied male persons exposed to boron both occupationally and via drinking water. The study investigated possible reproductive effects of boron exposure in workers employed in a boric acid production plant. Boron was analysed in biological samples (blood, urine, semen), in workplace air, in food, and in water sources. Unfavourable effects of boron exposure on the reproductive toxicity indicators (concentration, motility, morphology of the sperm cells and blood levels of folliclestimulating hormone (FSH), luteinizing hormone ( $\mathrm{LH})$, and total testosterone) were not observed. The mean calculated daily boron exposure (DBE) of the highly exposed subgroup was $14.45 \pm 6.57$ (range: $3.32-35.62$ ) $\mathrm{mg} /$ day.

An extension of this study investigated the relation between DNA-strand breaks (COMET assay, neutral and alkaline version) in sperm cells and sperm quality parameters. A correlation between blood boron levels and mean DNA-strand breaks in sperm was weak and DNA-strand breaks in sperm were statistically not different between control and exposed groups. It was concluded that boron exposures had no dose-dependent contribution in addition to already pre-existing DNA-strand breaks in the sperm cells. Weak but statistically significant correlations between DNAstrand breaks and motility/morphology parameters of sperm samples were observed in the neutral version of the COMET assay, while correlations between the same variables were statistically not significant in the alkaline version (Duydu et al. 2012).

In another independent study, (Duydu et al. 2018a) investigated possible boron-associated effects on male reproduction in workers $(n=212)$ under different boron exposure conditions in the boron mining area of Bigadic. The mean 
daily boron exposure (DBE) and blood boron concentration of workers in the "extreme" exposure group $(n=98)$ were $47.17 \pm 7.47$ (range: $7.95-106.8$ ) $\mathrm{mg} \mathrm{B} /$ day and $570.6 \pm 160.1$ (range: 402.6-1100) ng B/g blood, respectively. Boron-associated adverse effects on semen parameters, as well as on FSH, LH and total testosterone levels were not seen, even within the "extreme" exposure group.

Hundred and ninety-nine females residing in Bandirma and Bigadic participated in a study investigating pregnancy outcomes. The study group covered boron blood levels from low ( $<100 \mathrm{ng} \mathrm{B/g}$ blood, $n=143)$ to high $(>150 \mathrm{ng} \mathrm{B/g}$ blood, $n=27$ ) concentrations. The mean blood boron concentration and the mean estimated daily boron exposure of the high exposure group was 274.58 (range: 151.81-975.66) ng B/g blood and 24.67 (range: 10.47-57.86) mg B/day, respectively. In spite of the high levels of exposure, boronmediated adverse effects on induced abortion, spontaneous abortion (miscarriage), stillbirth, infant death, neonatal death, early neonatal death, preterm birth, congenital anomalies, sex ratio and birth weight of newborns were not observed (Duydu et al. 2018a, b). This negative outcome was supported by additional studies of possible DNA damage in the lymphocytes and buccal cells of females, assessed by Comet and micronucleus assays. No significant difference was observed in the DNA damage of the lymphocytes of B-exposed groups of female volunteers in Comet assay. Buccal micronucleus frequency observed in the high exposure group was even significantly lower than the low exposure group $(p<0.05)$ (Başaran et al. 2019a).

Boron-associated shifts in sex ratios at birth (based on decrease in Y- vs. X-bearing sperm cells) had been suggested based in studies in China (v.s.). Therefore, a new independent study on this particular topic was started and 304 male workers in Bandirma and Bigadic (Turkey) with different degrees of occupational and environmental exposure to boron were investigated (Duydu et al. 2019). Boron was quantitated in blood, urine and semen and the persons were allocated to exposure groups along B blood levels. In the highest ("extreme") exposure group $(n=69)$, calculated mean daily boron exposures, semen boron and blood boron concentrations were 44.9 [range 7.95-196] mg B/day, 1643 [range 188-1886] ng B/g semen and 554 [range 402-2000] ng B/g blood, respectively. Overall, an association between boron exposure and Y:X sperm ratios in semen was not statistically significant $(p>0.05)$. Also, the mean Y:X sperm ratios in semen samples of workers allocated to the different exposure groups were statistically not different in pairwise comparisons $(p>0.05)$. Additionally, a boron-associated shift in sex ratio at birth towards female offspring was not visible. These results did not support an association between boron exposure and decreased Y:X sperm ratio in males, even under extreme boron exposure conditions (Duydu et al. 2019).
This study was supplemented by an extension on 102 male workers who were occupationally exposed to boron from Bandırma and 110 workers who were occupationally and environmentally exposed to boron from Bigadic. DNA damage in the sperm, blood and buccal cells of 212 males was evaluated by Comet and micronucleus assays. No significant increase in the DNA damage in blood, sperm and buccal cells was observed in persons exposed to boron both occupationally and environmentally (Başaran et al. 2019b).

\section{Discussion and conclusion}

Experimentally, inorganic boron compounds (boric acid and borates) may exert toxic effects on reproduction. For these effects, a NOAEL (no-observed-adverse-effect-level) of $17.5 \mathrm{mg} \mathrm{B} / \mathrm{kg}$-bw/day has been identified by official bodies for the (male) reproductive effects of boron in a multigeneration study of rats (as the most susceptible species) and a NOAEL for the developmental effects in rats was identified at $9.6 \mathrm{mg} \mathrm{B/kg-bw/day} \mathrm{(WHO} \mathrm{1998;} \mathrm{ECHA} \mathrm{2010;} \mathrm{WHO}$ 2011).

By contrast, neither boron-related male reproductive nor developmental effects have been ascertained in human populations exposed to high B levels.

The exposure data of studies as discussed above are compiled in Table 1. The following conclusions can be drawn from this compilation:

- A comparison of estimated daily B exposure levels and measured B blood levels confirms the preference of biomonitoring data for a comparison of human field studies. This relates to both environmental and occupational field studies.

- The B blood level scaling clearly shows that high occupational B exposures reported in China and in Turkey are almost compatible.

- Compared to the B blood levels at the boron-related NOAELs for male fertility and for developmental toxicity in rats, the blood level means of the highest occupational exposure groups in China and in Turkey are lower by factors of $>4$ and $>2$, respectively. Part of the persons in the highest $\mathrm{B}$ exposure groups in China and in Turkey reach or exceed the experimental B blood levels at the NOAEL for developmental toxicity in rats. Part of the persons in the highest B exposure group in China reach or exceed the experimental B blood levels at the NOAEL for an impairment of (male) fertility in rats.

This demonstrates that there is no basic contradiction between the human and experimental reproductive toxicity data for boric acid/borates, as effect levels are definitely 
Table 1 Synopsis of human and experimental exposures to boric acid/borates and associated boron blood levels (means or median and range; values rounded to 2 digits); ranking of human studies according to exposure levels. Adopted from Bolt et al. (2012), updated and modified

\begin{tabular}{|c|c|c|}
\hline & Estimated daily B exposures & $\begin{array}{l}\text { B blood levels } \\
\text { (whole blood) }\end{array}$ \\
\hline Human studies & mg per day & ng B/g blood \\
\hline Turkey, env. (Şaylı et al. (1998; Korkmaz et al. 2007) (high dose "Group I") & $\begin{array}{l}6.8 \\
{[1.8-23]}\end{array}$ & - \\
\hline Argentina, env. (Igra et al. 2016) (total cohort of mothers) & - & $\begin{array}{l}130^{*} \\
{[0.73-610]^{*}}\end{array}$ \\
\hline Turkey, env. + occup. (Tüccar et al. 1998) (high exposure group) & $\begin{array}{l}14.5 \\
{[3.3-36]}\end{array}$ & $\begin{array}{l}220 \\
{[150-450]}\end{array}$ \\
\hline Turkey, env., females (Duydu et al. 2018b) (high exposure group) & $\begin{array}{l}25 \\
{[10-58]}\end{array}$ & $\begin{array}{l}280 \\
{[152-980]}\end{array}$ \\
\hline USA, occup. (Culver et al. 1994) ("high dust exposure group") & $\begin{array}{l}28 \\
-\end{array}$ & $\begin{array}{l}260 \\
\text { [up to 330] }\end{array}$ \\
\hline China, occup. (Scially et al. 2010; Robbins et al. 2010) (high exposure group) & $\begin{array}{l}37 \\
{[2.3-470]}\end{array}$ & $\begin{array}{l}500 \\
{[20-3600]}\end{array}$ \\
\hline Turkey, occup., males (Duydu et al. 2019) (“extreme” exposure) & $\begin{array}{l}45 \\
{[8.0-200]}\end{array}$ & $\begin{array}{l}550 \\
{[400-2000]}\end{array}$ \\
\hline Experimental studies & $\mathrm{mg} / \mathrm{kg}$ per day & ng B/g blood \\
\hline Rat NOAEL, fertility (Weir et al. 1972) & 18 & 2300 \\
\hline Rat NOAEL, devel. tox. (Price et al. 1996) & 9.6 & 1300 \\
\hline
\end{tabular}

Occup. occupational, env. environmental B exposure

*Assuming equal distribution of B between serum and blood cells (v.s., “Toxicokinetics of boric acid”)

higher compared to NOAELs. Human B exposures, even in the highest exposed cohorts, are too low to reach the blood (and target tissue) concentrations, which would be required to exert toxic effects on reproduction. In this context, it must be noted that the highest exposures reported in China and in Turkey truly represent the worst-case human exposure conditions that are feasible today. Therefore, concentrations of $\mathrm{B}$ within the body that exert reproductive toxicity in humans are not be reached under the conditions of human normal handling and use, including conditions of most extreme occupational exposures. Therefore, all relevant human study results are negative.

The question remains how this scientific situation is translated into the regulatory context. Chapter 3.7.2.3.1 of the Globally Harmonized System of Classification and Labelling of Chemicals (GHS) says: "Classification as a reproductive toxicant is made on the basis of an assessment of the total weight of evidence. This means that all available information that bears on the determination of reproductive toxicity is considered together. Included is information such as epidemiological studies and case reports in humans and specific reproduction studies along with sub-chronic, chronic and special study results in animals that provide relevant information regarding toxicity to reproductive and related endocrine organs"... In addition, chapter 3.7.2.3.2 says: "Toxicokinetic studies in animals and humans, site of action and mechanism or mode of action study results may provide relevant information, which could reduce or increase concerns about the hazard to human health"...

In essence, the present categorization of inorganic boron compounds (boric acid and borates) should be reconsidered.

Acknowledgements Open Access funding provided by Projekt DEAL. The authors' own field studies (2011-2017) were supported by Eti Mine General Management, Turkey.

Open Access This article is licensed under a Creative Commons Attribution 4.0 International License, which permits use, sharing, adaptation, distribution and reproduction in any medium or format, as long as you give appropriate credit to the original author(s) and the source, provide a link to the Creative Commons licence, and indicate if changes were made. The images or other third party material in this article are included in the article's Creative Commons licence, unless indicated otherwise in a credit line to the material. If material is not included in the article's Creative Commons licence and your intended use is not permitted by statutory regulation or exceeds the permitted use, you will need to obtain permission directly from the copyright holder. To view a copy of this licence, visit http://creativecommons.org/licenses/by/4.0/.

\section{References}

Abdelnour SA, Abd El-Haak ME, Swelum AA, Perillo A, Losacco C (2018) The vital roles of boron in animal health and production: a comprehensive review. J Trace Elem Med Biol 50:296-304

ATSDR [Agency for Toxic Substances and Disease Registry] (2010). Toxicological Profile for boron. Altanta, GA, USA, Nov 2010. 
https://www.atsdr.cdc.gov/ToxProfiles/TP.asp?id=453\&tid=80. Accessed 7 Jan 2020

Başaran N, Duydu Y, Üstündağ A, Taner G, Aydin S, Anlard HG, Yalçin ÖC, Bacanli M, Golka K, Schwerdtle T, Bolt HM (2019a) Environmental boron exposure does not induce DNA damage in lymphocytes and buccal cells of females-DNA damage in lymphocytes and buccal cells of boron exposed females. J Trace Elem Med Biol 53:150-153

Başaran N, Duydu Y, Üstündağ A, Taner G, Aydin S, Anlard HG, Yalçin ÖC, Bacanli M, Aydos K, Atabekoğlu CS, Golka K, Ickstadt K, Schwerdtle T, Werner M, Meyer S, Bolt HM (2019b) Evaluation of the DNA damage in lymphocytes, sperm and buccal cells of workers under environmental and occupational boron exposure conditions. Mutat Res Gen Tox En 843:33-39

Basoğlu A, Baspinar N, Tenori L, Vignoli A, Gulersoy E (2017) Effects of boron supplementation on peripartum dairy cows. Biol Trace Elem Res 179(2):218-225

Bolt HM, Başaran N, Duydu Y (2012) Human environmental and occupational exposures to boric acid: reconciliation with experimental reproductive toxicity data. J Toxicol Environ Health A 75(8-10):508-514

Chang BL, Robbins WA, Wie F, Xun L, Wu G, Li N, Elashoff DA (2006) Boron workers in China: exploring work and lifestyle factors related to boron exposure. AAOHN J 54(10):435-443

Chapin RE, Ku WW (1994) The reproductive toxicity of boric acid. Environ Health Perspect 102(Suppl 7):87-91

Culver BD, Shen PT, Taylor TH, Lee-Feldstein A, Anton-Culver H, Strong PL (1994) The relationship of blood- and urineboron to boron exposure in borax workers and the usefulness of urine-boron as an exposure marker. Environ Health Perspect 102(Suppl 7):133-137

Duydu Y, Başaran N, Üstündağ A, Aydın S, Ündeğer Ü, Ataman OY, Aydos K, Düker Y, Ickstadt K, Schulze Waltrup B, Golka K, Bolt HM (2011) Reproductive toxicity parameters and biological monitoring in occupationally and environmentally boronexposed persons in Bandırma, Turkey. Arch Toxicol 85:589-600

Duydu Y, Başaran N, Ustündağ A, Aydin S, Undeğer U, Ataman OY, Aydos K, Düker Y, Ickstadt K, Waltrup BS, Golka K, Bolt HM (2012) Assessment of DNA integrity (COMET assay) in sperm cells of boron-exposed workers. Arch Toxicol 86(1):27-35

Duydu Y, Başaran N, Ustündağ A, Aydın S, Undeğer U, Ataman OY, Aydos K, Düker Y, Ickstadt K, Waltrup BS, Golka K, Bolt HM (2016) Is boric acid toxic to reproduction in humans? Assessment of the animal reproductive toxicity data and epidemiological study results. Curr Drug Deliv 13(3):324-329

Duydu Y, Başaran N, Aydın S, Üstündağ A, Yalçın CÖ, Anlar HG, Bacanlı M, Aydos K, Atabekoğlu CS, Golka K, Ickstadt K, Schwerdtle T, Werner M, Meyer S, Bolt HM (2018a) Evaluation of $\mathrm{FSH}, \mathrm{LH}$, testosterone levels and semen parameters in male boron workers under extreme exposure conditions. Arch Toxicol 92(10):3051-3059

Duydu Y, Başaran N, Üstündağ A, Aydın S, Yalçın CÖ, Anlar HG, Bacanlı M, Aydos K, Atabekoğlu CS, Golka K, Ickstadt K, Schwerdtle T, Werner M, Meyer S, Bolt HM (2018b) Birth weights of newborns and pregnancy outcomes of environmentally boron-exposed females in Turkey. Arch Toxicol 92(8):2475-2485

Duydu Y, Başaran N, Yalçın CÖ, Üstündağ A, Aydın S, Anlar HG, Bacanlı M, Aydos K, Atabekoğlu CS, Golka K, Ickstadt K, Schwerdtle T, Werner M, Bolt HM (2019) Boron-exposed male workers in Turkey: no change in sperm Y: X chromosome ratio and in offspring's sex ratio. Arch Toxicol 93(3):743-751

ECHA [European Chemicals Agency] (2010). Annex XV dossier. Proposal for identification of a substance as substance of very high concern (SVHC). Substance name: Boric acid. EC Number: 233-139-2/234-343-4. CAS Number: 10043-35-3/11113-50-1.
European Chemical Agency, Helsinki. https://echa.europa.eu/ de/registry-of-svhc-intentions/-/dislist/details/0b0236e180 e4b39c. Accessed 7 Jan 2020

Fail PA, George JD, Seely JC, Grizzle TB, Heindel JJ (1991) Reproductive toxicity of boric acid in Swiss (CD-1) mice: assessment using the continuous breeding protocol. Fund Appl Toxicol 17:225-239

Harari F, Langeén M, Casimiro E, Bottai M, Palm B, Nordquist H, Vahter M (2015) Environmental exposure to lithium during pregnancy and fetal size: a longitudinal study in the Argentinean Andes. Environ Int 77:48-54

Hasegawa R, Hirata-Koizumi M, Dourson ML, Parker A, Ono A, Hirose A (2013) Safety assessment of boron by application of new uncertainty factors and their subdivision. Regul Toxicol Pharmacol 65(1):108-114

Heindel JJ, Price CJ, Field EA, Marr MC, Myers CB, Morrissey RE, Schwetz BA (1992) Developmental toxicity of boric acid in mice and rats. Fund Appl Toxicol 18:266-272

Heindel JJ, Price CJ, Schwetz BA (1994) The developmental toxicity of boric acid in mice, rats, and rabbits. Environ Health Perspect 102(Suppl 7):107-112

Igra AM, Harari F, Lu Y, Casimiro E, Vahter M (2016) Boron exposure through drinking water during pregnancy and birth size. Environ Int 95:54-60

Jansen J, Andersen J, Schou JS (1984) Boric acid single dose pharmacokinetics after intravenous administration to man. Arch Toxicol 55(1):64-67

Jensen GM, Moore LG (1997) The effects of high altitude and other risk factors on birthweight-independent or interactive effects? Am J Public Health 87(6):1003-1007

Korkmaz M, Şaylı U, Şaylı BS, Bakırdere S, Titretir S, Ataman OY, Keskin S (2007) Estimation of human daily boron exposure in a boron-rich area. Brit J Nutr 98:571-575

Korkmaz M, Yenigün M, Bakırdere S, Ataman OY, Keskin S, Müezzinoğlu T, Lekili M (2011) Effects of chronic boron exposure on semen profile. Biol Trace Elem Res 143(2):738-750

Krishnan BB, Selvaraju S, Gowda NKS, Subramanya KB, Pal D, Archana SS, Bhatta R (2019) Dietary boron supplementation enhances sperm quality and immunity through influencing the associated biochemical parameters and modulating the genes expression at testicular tissue. J Trace Elem Med Biol 55:6-14

Ku WW, Chapin RE, Moseman RF, Brink RE, Pierce KD, Adams KY (1991) Tissue disposition of boron in male Fischer rats. Toxicol Appl Pharmacol 111:145-151

Ku WW, Chapin RE, Wine RN, Gladen BC (1993) Testicular toxicity of boric acid (BA): relationship of dose to lesion development and recovery in the F344 rat. Reprod Toxicol 7:305-319

Lanoue L, Taubeneck MW, Muniz J, Hanna LA, Strong PL, Murray JJ, Nielsen FH, Hunt CD, Keen CL (1998) Assessing the effects of ow boron diets on embryonic and fetal development in rodents using in vitro and in vivo model systems. Biol Trace Elem Res 66(1-3):271-298

Marat I, Arstan M, Galymzhan Y, Timur J, Yerbolat I, Almasbek Y (2018) Impact of chromium and boron compounds on the reproductive function in rats. Toxicol Ind Health 34(6):365-374

Moore JA (1997) An assessment of boric acid and borax using the IEHR evaluative process for assessing human developmental and reproductive toxicity of agents. Expert scientific committee. Reprod Toxicol 11(1):123-160

Murray FJ (1998) A comparative review of the pharmacokinetics of boric acid in rodents and humans. Biol Trace Elem Res 66(1-3):331-341

Nielsen FH (2000) The emergence of boron as nutritionally important throughout the life cycle. Nutrition 16(7-8):512-514

Nielsen FH (2008) Is boron nutritionally relevant? Nutr Rev $66: 183-191$ 
Price CJ, Strong NL, Marr MC, Myers CB, Murray FJ (1996) Developmental toxicity NOAEL and postnatal recovery in rats fed boric acid during gestation. Fund Appl Toxicol 32:179-193

Price CJ, Strong PL, Murray FJ, Goldberg MM (1997) Blood boron concentrations in pregnant rats fed boric acid throughout gestation. Reprod Toxicol 11:833-842

Robbins WA, Xun L, Jia J, Kennedy N, Elashoff DA, Ping L (2010) Chronic boron exposure and human semen parameters. Reprod Toxicol 29:284-190

Şaylı BS (1998) An assessment of fertility in boron-exposed Turkish subpopulations: 2. Evidence that boron has no effect on human reproduction. Biol Trace Elem Res 66(1-3):409-422

Şaylı BS, Tüccar E, Elhan AH (1998) An assessment of fertility in boron-exposed Turkish subpopulations. Reprod Toxicol 12:297-304

SCCS [Scientfic Committe on Consumer Safety; EU Directorate for Health and Consumers] (2010) Opinion on boron compounds. Adopted 22 June 2010, Revision 28 Sep 2010. https://ec.europ a.eu/health/scientific_committees/consumer_safety/docs/ sccs_o_027.pdf. Accessed 7 Jan 2020

Scially AR, Bonde JP, Brüske-Hohlfeld I, Culver BD, Li Y, Sullivan FM (2010) An overview of male reproductive studies of boron with an emphasis on studies of highly exposed Chinese workers. Reprod Toxicol 29:10-24
Tüccar E, Elhan AH, Yavuz Y, Şaylı BS (1998) Comparison of infertility rates in communities from boron-rich and boron-poor territories. Biol Trace Elem Res 66(1-3):401-407

Usuda K, Kono K, Orita Y, Dote T, Iguchi K, Nishiura H, Tominaga M, Tagawa T, Goto E, Shirai Y (1998) Serum and urinary boron levels in rats after single administration of sodium tetraborate. Arch Toxicol 72(8):468-474

Weir RJ, Fisher RS (1972) Toxicologic studies on borax and boric acid. Toxicol Appl Pharmacol 23:351-362

WHO [IPCS, International Programme on Chemical Safety] (1998) Environmental Health Criteria 204: Boron. World Health Organization, Geneva

WHO (2011). Guidelines for drinking-water quality, fourth edition. https://www.who.int/water_sanitation_health/publications/dwqguidelines-4/en/. Accessed 7 Jan 2020

Publisher's Note Springer Nature remains neutral with regard to jurisdictional claims in published maps and institutional affiliations. 